\title{
Content and language integrated learning and teaching in digital class: Latvia experience
}

\author{
Zenta Anspoka*, Inese Eglite** \\ *University of Latvia, Latvia; zenta.anspoka@lu.Iv \\ **University of Latvia, Latvia; inese.eglite@inbox.Iv
}

\begin{abstract}
The topicality of the research relates to the problem that in the last ten or more years approximately 300 thousand Latvian people live outside Latvia. Together with parents are living children in more than 15 countries. One of the tasks with national importance is to help to children and their family to save or to develop Latvian language and culture traditions, to give possibility to return to Latvia and to continue education process in Latvia. Latvian Language State Agency provides an opportunity to learn Latvian as a State language and to get acquainted with Latvian culture traditions, to understand social events, relationships in the society. One of possibility for this is to plan and to realize integrated content and language learning and teaching process for children outside Latvia in a digital class. That means to use Classflow site and another digital tools (Skype, a mobile phone and toys with special computer software, interactive blackboard programs etc.). Aim of the study is to analyze the experience of children living outside Latvia to learn integrated content and language with digital tools. Research is based on analyses of theories about content and language integrated learning, communicative approach for language acquirement and teacher's professional competence. Empirical research is based on pedagogical observation and teacher's survey results. As respondents are 120 children (6-14 year old) in 22 groups/digital classes and 16 teachers.
\end{abstract}

Keywords: digital class as a work organization form, content and language integrated learning (CLIL), teacher's professional competence

\section{Introduction}

Now more than 300 thousand Latvian citizens live abroad in more than 15 countries of the world. Among them are families with children who do not plan to return to their ethnic homeland soon, as well as those who intend to do so and enroll children in the Latvian education system. Regardless of the purpose of each person in terms of returning to Latvia, each of them is the national value of the Latvia, and it is essential to strengthen the link between them and the state. The Latvian Language State Agency implements this national policy and this work has been expanded in recent years to become purposeful and long-term.

As the Latvian language is a great value and the basis of Latvian identity, much has been done to ensure the learning of the Latvian language in both so-called Sunday schools and summer schools. One of the latest ways to promote a more regular and quality learning of the Latvian language is to use one of the socalled distance learning form - digital class. The approved digital class in Latvia is the one developed on the Classflow site. ClassFlow is a comprehensive teaching and learning platform - an online learning management tool that allows you to collaborate with the teacher regardless of where your child is located. The technical possibilities allow the children to meet regularly and create interactive content and methodology for learning language and Latvian culture, actively involve children in class and quickly evaluate achievements. Classflow site gives possibility to use different digital tools: Skype, a mobile phone and toys with special computer software, interactive blackboard programs etc.

Aim of the study is to analyze the experience of children living outside Latvia to learn integrated content and language with digital tools.

Research is based on analyses of theories about content and language integrated learning (CLIL), communicative approach for language acquirement and teacher's professional competence. Empirical research is based on pedagogical observation and teacher's survey results. As respondents are 120 children (6-14 year old) in 22 groups/digital classes and 16 teachers.

\section{Results and discussion}

Language is not only a mean of communication. Language is also a mean of acknowledging human thinking, self-affirmation and ethnicity. Language skill includes the skill to perform speech activities depending on the communication situation and one's own intentions. The exploration of language is not 
possible without the study of culture, which includes social behaviour and situations characteristic for the particular language users (Hall 2002).

One of the solutions to achieve a high-quality language learning process is to plan and carry out two important tasks in the teaching and learning process - to help to children to acquire different content and purposefully to use language for this. One of important task is to use content and language integration as a teaching and learning approach (CLIL). CLIL provides an opportunity not only to acquire content and language in mutual relation, but also perceive learning as a purposeful activity, in which everything is mutually related and important (Marsh 2012).

Topicality of CLIL is determined by several factors. The following factors could be mentioned as the most important ones: ethnic and linguistic diversity of children groups, policy of national education and social integration and the goal of the developed learning content and the envisaged approach for its acquisition to eliminate fragmentation and duplication, provide succession of learning content acquisition and an opportunity for each children to see interconnections between the acquired in different areas, apply their knowledge in practice (Anspoka 2019).

CLIL encourages not only the learning of language and culture in a mutual interaction, but also raises teacher's and learner's expectations, increases vocabulary learning skills and grammatical awareness, motivates students' independence, improves language skills, communication skills, generates positive attitudes (Coyle 2007).

Pedagogical practise shows that the CLIL approach enables the teacher to vary methodology, as in the learning process the content does not dominate, but rather the way how the children acquires it, and it is important for child's personal development. According to pedagogical observation content is organized thematically. Specific topics suitable for the language learner make it possible to perceive the interrelations between language and culture, language and universe, to learn different language functions in relation to the age and traditions of a nation, to expand the cultural point of view.

Since the topics are interconnected, the teacher encourages the children to activate the previous experience and improve it, gradually move towards learning new knowledge and skills: speak, read or write in Latvian about various events, facts relevant to the child's age, and analyze them at each new lesson. The thematic approach does not break the system, even when issues relevant to the children are included in a situation, unexpected events or facts, etc., are discussed. The child learns to understand that language is not only a means of communication, but also a means of thinking, self-awareness and ethnicity.

By improving own speech skills, a child awaits to see an achievement in this respect. If he or she does not see a point in doing these tasks, if the acquisition of new things is not based on previous experience, there comes frustration since the expectations have not delivered a lasting satisfaction. In this stage a child feels disappointed, becomes stressed, experiences inner anxiety that often leads to isolation, protest and reluctance to speak, and later, possibly, a refusal to read and write. This is especially dangerous during preschool and early school age, when learning a language as a meaningful process has just begun. It is at this age that a child discovers the world and learns to live in it physically, emotionally and socially. For this reason, during the speech development process the choice of learning contents as well as the teaching methodology and the achievement assessment system must be well thought through (Anspoka 2011).

The tasks, in which the child can use the language per his level of knowledge - to tell, to name what he has seen or heard, to create a dialog, to describe the objects or creatures, to ask and answer, are very important whatever if you learn traditionally in a classroom with direct contact with a teacher or from the distance.

\section{Digital class as a nowadays phenomenon for teaching and learning}

Nowadays distance learning tools are becoming more and more important. It is determined by different circumstances. One of them is that those who learn do not live in the country whose curriculum is learned. We can also talk about the digital class as a work organization form nowadays. It is a class that exists on a digital platform and uses different digital tools.

The digital class as a form of work organization meets the same general requirements, which also apply to the so-called traditional class, which provides definite time for specific task ( 30 or 40 minutes depending 
on the child's age), each lesson has the goal, while the work is planned for children with different backgrounds and abilities of previous experience, new lesson is a continuation of the previous lesson depending on the purpose of the study, each lesson has certain structure, as well adequate culture of communication, hygiene requirements etc. are ensured (Žogla 2001).

At the same time, the digital class also has specific features, and the most common are:

- children can learn together in different parts of the world, if they live in the same or similar time zone;

- teacher and children has indirect contact; they see each other only on the screen;

- the technical possibilities allow to provide a greater variety of visual materials and the activity of the child during the learning process;

- the teacher can use the experience of different countries in the education system when planning lesson content and choosing a methodology;

- previous work can be saved and used during other lessons;

- the child learns in a more comfortable environment and time, for example, at home;

- the child can, independently and together with the teacher, use or improve his previous experience in working with a computer, Skype program, etc. information technology tools.

According to the current procedure of the Latvian Language State Agency, children from different countries of the world meet each other and teacher in a digital classroom twice a week. The main prerequisites are the residence country of children of the same or at least similar time zone, as well as, if possible, the age and language proficiency level.

Pedagogical observation shows that the latter conditions are the most difficult to implement, therefore successful work is based on the teacher's professionalism to prepare the content of the lesson and to use the methodology that allows individualize and differentiate the work regardless of the child's needs and abilities. Classes take place after lessons or after-school activities in the school or pre-school in the residence country. As children have a different level of knowledge of the Latvian language and the ability to use information technologies, parents play significant role in helping children to cope with the use of the website and the execution of the tasks. This applies to pre-school and primary-school children. Adolescents work independently and they do not need assistance of the parents.

Children get acquainted with work rule during the first lessons for more successful cooperation, with the teacher and the parents agree on a certain gesture, sign, etc., use. This work approach allows understanding in the digital environment when the task is completed, who will be the first to answer, how to follow speech behavior and language culture, respect the one who is speaking, asks the question or provides the answer. Children also learn essential technical rules such as sound muting rules in Skype when listening to a song, reading a text, or watching a movie. It is also important to have common rituals, with which the lesson begins and ends, the teacher's emotional intelligence, and the attitude to every child. Since the teacher can not invite each child to come, to encourage him via direct contact, the teacher is forced to think both about its voice tempo, the pace and empathy so that the child could feel good and be motivated to observe, listen and perform the tasks during the lesson.

When interviewing digital class teachers, all of them admitted that the positive emotional environment makes the child to forget about fatigue after school or hobby groups, stimulates working with peers from different countries. To form each child's sense of belonging to their group, digital class teachers organize targeted birthdays or name days, celebrations of traditional Latvian holidays, important holidays and remembrance days of Latvia. It allows children to learn different traditions, folk songs, and poems, to tell them or sing in Latvian. Children can compare, how and what is celebrated in their home countries and in Latvia (Martin day, Christmas, Meteni, Easter, etc.). Consequently, it can be argued that culturally oriented content and Latvian language has been studied in a nonintrusive, meaningful process.

\section{Teacher's professional competence - guarantor for the quality of work in the digital classes}

At the same time, the professionalism of the Latvian language teacher in many aspects can determine that the learning process of the Latvian language can become a beautiful and emotional meeting not only with the Latvian language, but also with the Latvian lifestyle, Latvian cultural values in many families even 
after several years. Consequently, at the level of the state education policy, it is intended that this important work would be carried out by specially trained teachers.

One of the most important questions of teacher's professionalism is the understanding that CLIL is a psychological, pedagogical and social process in which the child progressively acquires facts and values of Latvian culture and other cultures, language regularities, skills to use them, develops the sense of language as a speaker and the ability to write based on the acquired knowledge, to understand and assess the its own and other people speech. The child's conceptual thinking, perception of the world and attitude towards it develops along with the language.

When preparing digital teaching materials, the development and maintaining of the rich language is crucial. It is important for the child to hear and learn to perceive and understand language-specific sounds, semantics, textual and stylistic peculiarities step by step. Synonyms and imaginative means can not be ignored. On the contrary, it is important for the child to get used to the variety of expressions. If the child is confused, doesn't understand, it's always possible for the teacher to change the way of speech, to offer an explanation and use other pedagogical tools (Anspoka \& Stangaine 2017).

It is important for a child to understand the language from the context, because only the context reveals not only the meaning of the word, but also the properties of phenomena, their quantity, states or sequence. Even it is easier for a child to learn the grammatical form of words, word derivations, compound words, etc., if these words are used in a context. At the same time, the child learns to understand that each word has two important features - sound and meaning. Mechanical memorizing the words, teaching without understanding of their meaning does not give the desired result. It is important for the child to create a match between the image and the name.

Reading aloud has a great value. The text read by the teacher or recorded text, the reader's voice intonations, timbre and tempo create associations in the child, he perceives the values expressed in the text, making them the benefits of his personality. Listening to the text, the child activates imagination, it creates emotional experience.

It is worth mentioning the use of multiple languages without fear of any harm to the child. Physically and mentally healthy, growing between two languages and two cultures, child develops higher metalinguistic skills, he learns more socio-cultural attitudes and the ability to adapt better to different cultural environments. The pedagogical process can not avoid the interactions between different languages, but at the same time it is necessary to be aware that languages do not differ from one another simply by the fact that one thing in one language has one name, in another language another name. A vocabulary is not the most important part of a language, although the non-linguist has the tendency to notice straightforward isolated words. More important than individual words is the way in which each language combines them into word groups and which are selected by us in a particular case. You should first help a bilingual child to formulate a thought, learn to choose the appropriate words, and not necessarily mechanically searching for corresponding "isolated" word (Anspoka \& Stangaine 2017, Anspoka \& Stangaine 2016).

The observation of the pedagogical process and the survey of teachers show that the work of Latvian language teacher with children from outside Latvia is not only about helping a child learn the words, phrases or sentences, but also how gradually and slowly to introduce the Latvian traditions, games, and most importantly - to convince the child that people, regardless of the place of residence, share the same basic values - honesty, kindness, sincerity and respect for each other. Teacher of Latvian language must be prepared to work simultaneously with children who have the experience of the Latvian language, and with children and their parents who doesn't speak Latvian. It is a real professional challenge to find the way to each child's mind and heart step-by-step. Being aware of the benefits of the digital world, it is not possible to ignore the fact that it also changes the child's attention structure, emotional contact.

As the pedagogical practice observations show, the child may be more likely to distract attention from what should be done, to lose contact with a teacher and classmates in a digital classroom, if it doesn't know how to work with Skype program or resources provided on the Classflow website, in case of technical difficulties with the computer, Internet connection, etc. The child's attention can be distracted by the great colorfulness, the various effects that can be achieved through various information technology tools, and 
the fact that the teacher's presence is not direct. When planning and organizing the work in a digital classroom to help the child learn Latvian traditions in an integrated way, information about Latvian nature, social events, prominent personalities and basic language skills, the teacher should consider that the child's participation in the study process is possible if the content is equally important in the classroom, as language learning methodology and assessment methodology, which allows the child to see their own, even the smallest achievements.

When working on the Classflow website, the teacher must specially consider how to enhance learning motivation. If half of the children speak Latvian both in the family and during learning process in the digital classroom, then the other half of the child, per their parents' will, only works in the digital classroom. Consequently, Classflow and Skype become the only place where children meet with their peers and learn language spoken by one of their parents.

As teachers admit, per observations, learning becomes more meaningful if the language is used not only for learning the regularities of syntax or morphology, but at the same time for learning new, interesting information and exchange it with peers. It provides an opportunity to get to know and understand the Latvian as an ethnic culture, to promote the development of sociocultural competence, and to promote the use of acquired knowledge and skills in practical situations.

It is the natural development of language or language necessary for communication. Using language for learning content, communication becomes meaningful as language is a means of communication, not the goal (Beikers 2002). Individual work, the work in pairs and groups is equally important so that teacher could collaborate on the Classflow website, using CLIL.

The Latvian language skills for every child living outside Latvia helps to keep not only the sense of belonging to Latvia and study about Latvian nature, people, traditions, etc., but also allows you to return to your homeland at any time and integrate in society and the education system within short period.

The participation in ClassFlow depends on how successful the teacher created tasks so that children with language proficiency would have enough time to finish them especially those who need more time and effort to complete their tasks.

Observations in the pedagogical process show that the work on the ClassFlow site enables children not only to learn the language but also to get acquainted with their peers from other countries, to find out new information. In turn, the information technology tools offered by Classflow also allow include games, to send drawings, letters, and so on. It also promotes successful socialization of children, tolerance to different cultures. Purposefully planned game-lessons are aimed at letting a child to get used to perceiving statements within a text, to learn to distinguish certain words in hearing and later, as a child learns to read and write, to read them with an appropriate intonation, if necessary to emphasize specific words in a text, to pay attention to capital letters and punctuation at the end of sentences, text formatting etc. Specially prepared digital learning materials, if used purposefully, enable to use senses (sight, hearing, touch, movement etc.), based on which associations with previously obtained experience are created. The use of digital learning materials raise a child's activity, as a child sees that, just like the adults, he or she, too, can obtain information by reading or can pass it on to others in writing.

Classflow digital tools provide an opportunity to compare objects, names, to group them per various characteristics, to move them around, to combine, to separate, to shrink or to enlarge them, to colour or to mark them, to write, to edit or to check the results of work, to evaluate and listen to records or to record own speech, to add interactive online resources, etc.

The results of the study suggest that the child's experience of reading or writing in the native language is equally important. If the child goes to school and has mastered basic language skills of another language, he can more easily deal with the tasks of the Latvian language. If the child is at pre-school age and does not yet read or write in any of the languages, then excellent support for him is a teacher with his parents.

Both in primary school and at school, parent meetings are organized via Skype program during which language learning issues and problems have been discussed. Parents receive a feedback that gives them an opportunity to see where they can be useful in the process of their child's education. As pedagogical practice shows, parents also advise the teacher on how to better organize work, respecting each child's experience, character, etc. Teachers in the digital class recognize that it is very important to have a good 
contact with the parents of children, and there is a reason for that as the desire to provide their children the opportunity to learn Latvian along with the studies at the school of the country of residence demonstrates their dignified attitude towards Latvia, against Latvian traditions, against people from families with whom they have more close or ulterior contact. Therefore, children and their parents are more intellectually, emotionally and physically burdened.

\section{Conclusions}

- The digital class in Classflow site as a teaching and learning platform on the Internet, allows you to collaborate with a teacher, regardless of the location of the child. The technical possibilities allow the children to meet regularly and create an interactive content and methodology for learning the language and Latvian culture.

- The Classflow website provides opportunities for effective time management, an easy and detailed evaluation process, interesting and interactive presentation techniques, support for students' individual development and assessment, home-learning opportunities and integrated language and content learning and teaching (CLIL).

- CLIL helps the child to learn not only language but also the facts and values of Latvian culture and other cultures, to develop a sense of language as a speaker and writer, ability to recognize and evaluate its own and other people speech based on the gained knowledge. The child's conceptual thinking, perception of the world and attitude towards it develops along with the language.

- The prerequisite for the successful learning of the content and language is the creation and maintenance of the rich language environment in the thematic content, as topic can be used as the tool for perceiving the speech and using language resources depending on it.

- Considering that work in the digital environment can also distract the child's attention, the child may lose the contact with the teacher and classmates, especially, if he is unable successfully to use the Skype or resources provided on the Classflow website when there is a technical problem with the computer, Internet connection etc., then the teacher, when planning and organizing the work to help the child to learn the language and the Latvian national traditions in the integrated way, information about the nature of Latvia, social events, the most prominent personalities, should be aware that a child's successful participation in the study process is possible if not only content is equally important in the class but also methodology provided for learning and assessment methodology, which allows the child to see its own, even the smallest achievements.

- Equally important is cooperation with parents of children, since the quality of lessons and the planning of future work with respect to children's needs depends on parental support.

- The teacher must be able to persuade both children and their parents that the Latvian language skills for a child living outside of Latvia help to keep not only the sense of belonging to Latvia and acquire knowledge about Latvian nature, people, traditions, etc., but also allows you to return to your ethnic homeland at any time and integrate in society and the education system in a short time.

\section{References}

Anspoka, Z. (2019). Pamatizglitīibas skolotāja profesionalitāte mācību satura un valodas integrētas apguves nodrošināšanai. [Comprehensive Teacher's Professionalism for Content and Language Integrated Provision] In: Society. Integration. Education. Proceedings of the International Scientific Conference. Volume II, May 24th -25th, 2019, 17-26.

Anspoka, Z. \& Stangaine, I. (2017). Bilingvālu bērnu runas izpēte - Veltas Rūḳes - Dravinas pētijumi un projekta "Latviešu valodas monolingvāla un bilingvāla apguve: rīki, teorijas un lietojums" rezultāti. [The survey of bilingual children's speech: the results by Velta Ruke-Dravina and results of the project "Latvian Language in monolingual and bilingual acquisition: tools, theories and applications"] Bērna valoda Latvijā 21. gadsimtā III. Rīga: Zinātne, 2017, 42 -55 .

Anspoka, Z. \& Stangaine, I. (2016). Divvalodīga bērna ieguvumi: teorija un prakse. [Bilingual advantages in Children: thery and practice] Bērnu valoda Latvijā 21. gadsimtā II. Zinātnisko rakstu krājums. Rīga: RaKa, 107-118. (in Latvian)

Anspoka, Z. (2011). Child speech development at pre-school and at School: Aspects of Successive Learning. Adverba lïberorum. Linguistics \& Pedagogy \&Psychology. Pie bērnu vārdiem: valodniecība, pedagoǵija, psiholoǵija, 3 (1), 46- 
59.

Beikers, K (2002). Bilingvisma un bilingvālās izglïtības pamati [Foundations of Bilingual Education and Bilingualism]. Rīga: Nordika.

Coyle, D. (2007). Content and language integrated learning: Motivating learners and teachers in the CLIL teachers tool kit: A classroom guide. Nottingham: The University of Nottingham.

Hall, J. K. (2002). Teaching and researching language and culture. London: Longman/Pearson.

Marsh, D. (2012). Content and Language Integrated Learning (CLIL). A Development Trajectory. University of Córdoba. helvia.uco.es/xmlui/bitstream/handle/10396/8689/2013000000658.pdf

Žogla, I. (2001). Didaktikas teorētiskie pamati. [Didactic's teorethical foundations] Rīga: RaKa. 